\title{
INFLUENCE OF STEEL REBAR UNIFORM CORROSION ON REINFORCED CONCRETE STRUCTURES`STRENGTH
}

\author{
${ }^{1}$ Blikharskyy Ya.Z., PhD, Associate Professor, \\ Yaroslav.Z.Blikharskyy@lpnu.ua, ORCID: 0000-0002-3374-9195 \\ ${ }^{1}$ Kopiika N.S., student, \\ kopijka.nadija.1999@gmail.com, ORCID: 0000-0003-2270-4028 \\ ${ }^{1}$ Lviv Polytechnic National University \\ 12 st. S. Bandera, Lviv, 79013, Ukraine
}

\begin{abstract}
Wide usage of reinforced concrete structures in various areas could be explained because of the number of its advantages, which are in turn the result of this material artificial and composite character. However, the number of complicating aspects should be taken into consideration, including the influence of aggressive environment and, subsequently, the corrosion processes in both concrete and reinforcement. Corrosion impacts on existing structures nowadays are remarkably significant. Therefore, this article aims to identify and describe the major factors of corrosion process, considering, in particular the development of such processes in thermally strengthened rebar. As an example is taken the uniform type of corrosion in steel bar and its major influences on reinforced concrete element reliability. In addition, the literature review is conducted and perspective ways of proposed technique development and further analytical and experimental investigations are described.
\end{abstract}

Keywords: corrosion in RC elements, uniform steel corrosion, thermally strengthened rebar, analytical modeling.

Introduction. Remarkable prevalence of reinforced concrete structures in various fields of application [1,2], could be associated with the number of its' advantages including variety of possible structural and architectural forms, high durability and strength, rather low price due to availability of local materials and small amount of operation and care costs $[2,3]$. All the above indicated positive parameters could be obtained due to artificial and composite character of this material which is the result of long-history development and scientific research. However, there is still the number of complicating aspects which should be taken into consideration, among which the most critical one is its low maintenance to aggressive environment [4]. The corrosion process in reinforced concrete elements has complicated synergic character due to complex complementarity of individual components of concrete along with artificially generated properties of high-strength reinforcement.

Therefore, for complete analysis of corrosion process in both steel bar, as well as in reinforced concrete structure generally, the number of theoretical and experimental investigations is required.

Problem formulation. Considering the fact of significant impacts of corrosion on different application fields, infrastructure and construction industries, its reliable and complex evaluation is very important. Thus, the purpose of this work is to identify and describe the major factors of corrosion process in the most complex way. Objectives of the article include identification of uniform corrosion influences on steel reinforcement and on reinforced concrete element in general and also evaluation the expediency of different analytical techniques usage.

Analysis of recent research. Peculiarities of RC structures` life cycle, their respond to different external actions and complex compatible performance of individual components have been widely discussed in the number of studies $[5,6]$. Thus, among the most popular areas of scientific studies there is research on possible changes of reinforcement steel microstructure by its thermal strengthening and corrosion protection [7-9]. For example, as was stated in works of Toth L., et al.,

Bulletin of Odessa State Academy of Civil Engineering and Architecture, 2020, no. 79, page 34-42 
2018, [10], thermal strengthening could result in complete microstructural changes in reinforcement steel and thereby, complication of corrosion processes development.

Authors typically pay attention to different responds of various types of steels to aggressive actions [4, 11-13]. Noticeable is the article of Fahim A. et al. (2017), [11] and Sharanya et.al. (2016) [4] providing deep comparative analysis of reinforcement material composition as the factor of steel resistance to corrosion. Mild steel rebar and stainless steel subjected to $\mathrm{NaCl}$ action are analyzed and recommendations for further research are given. Shi et al. (2017) in the study [12] in addition emphasizes on interfacial zone defects`impact on steel behavior under chloride attack. Also attention should be paid to chemical composition of both concrete and reinforcement as well as to coating thickness $[6,13]$.

In general, the most of experimental and theoretical investigations concerning corrosion processes following factors are discussed: the state of corrosion development and stress-strain state of RC element, as well as possible local damages of the material, zones with non-uniform composition of steel and surrounding concrete. In addition, attention should be paid to specifics of aggressive environment and presence of internal stresses along the steel bar cross-section.

In this article the general attention will be paid to specifics of corrosion processes development in thermally-strengthened rebar due to its heterogeneous characteristics along the cross-section.

Materials and methods of research. The corrosion uniform distribution is evaluated in the article. In order to determine the most remarkable aspects of the degradation process and to obtain reliable data analytical investigation was conducted. The theoretical modelling included the material properties modelling for thermally strengthened rebar taking into account non-uniform distribution of material properties along the cross-section. In addition, the set of calculations was performed, which took into account geometrical and chemical specifics of rebar material. The particular levels of corrosion damages and material degradation were taken into account in calculations.

Analytical investigation. The theoretical analysis is conducted in order to fully evaluate the influence of corrosion processes on steel bars ` properties and corresponding reliability of reinforced concrete elements. Material properties are considered according to following assumptions.

Analytical modeling is conducted for the samples of $\varnothing 20 \mathrm{~mm}$ A500C thermally strengthened rebars` with non-uniform material properties` discussed in previous research (Blikharskyy Ya.Z, 2019, [14]), Fig.1.

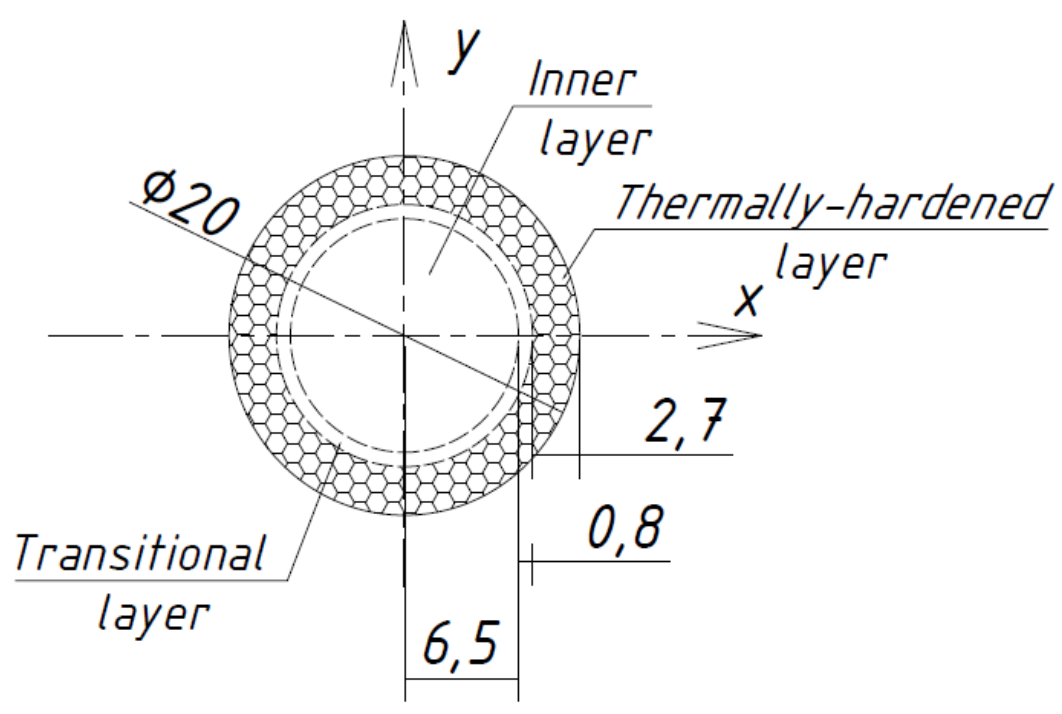

Fig. 1. Non-uniform material parameters for thermally strengthened rebar 
As could be seen on the Fig.1, the rebar cross-section could be divided into three zones:

- the thermally-hardened layer with the depth of $\delta^{I}=2,7 \mathrm{~mm}$ and the yield strength of $\sigma_{0,2}^{I}=650 \mathrm{MPa}$;

- the transitional layer properties will be formulated with the use of linearization along its thickness $\delta^{I I}=0,8 \mathrm{~mm}$. The limit yield strength is averaged as:

$$
\begin{gathered}
\frac{d}{d x} \sigma_{0,2}^{I I}=\lim _{x \rightarrow \infty} \frac{d}{d x_{i}} \sigma_{0,2 i}=\frac{\sigma_{0,2}^{I}-\sigma_{0,2}^{I I I}}{\delta^{I I I}}=\frac{560-440}{0,8}=150 \mathrm{MPa}, \\
\sigma_{0,2}^{I I}=\sigma_{0,2}^{I}-0,5 \delta^{I I} \cdot \frac{d}{d x} \sigma_{0,2}^{I I}=545 \mathrm{MPa} ;
\end{gathered}
$$

- the inner layer is not subjected to thermal transformations and has the lower yield strength value equal to $\sigma_{0,2}^{I I I}=440 \mathrm{MPa}$. This zone, henceforward called as 'core' has the thickness of $\delta^{I I I}=6,5 \mathrm{~mm}$.

After stresses in steel rebar exceed the level of the yield strength $\sigma_{0,2}$ typical is the strain increase without stress increment and interruption of compatible work of steel and concrete. Thus during calculations is considered the work of steel rebar within the elastic state, when $\sigma \leq \sigma_{0,2}$.In order to use traditional assumptions while element calculation the limit stress value for bar material is accepted as the yield strength for corresponding layer which at this particular state of corrosion spreading will be subjected to aggressive action of environment. Henceforth $[\sigma]=\sigma_{0,2}$.

The corrosion spread in thermally strengthened rebar is rather complicated process due to synergic action of the wide range of factors. Therefore, in this article the mathematical computation and experimental investigations are conducted for uniform distribution of corroded layer in radial direction (Fig.2).

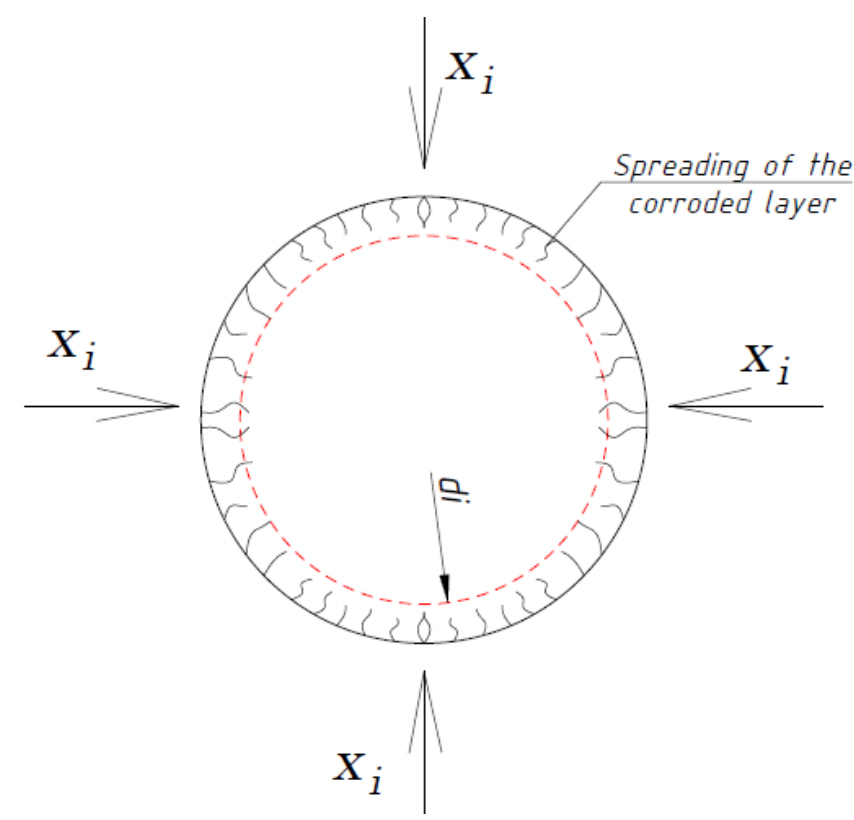

Fig. 2. Uniform distribution of the corrosion in steel bar

It is assumed, that the load is applied in the section center of gravity and could be considered as the concentrated force of certain limit value as shown on the Figure 3. 


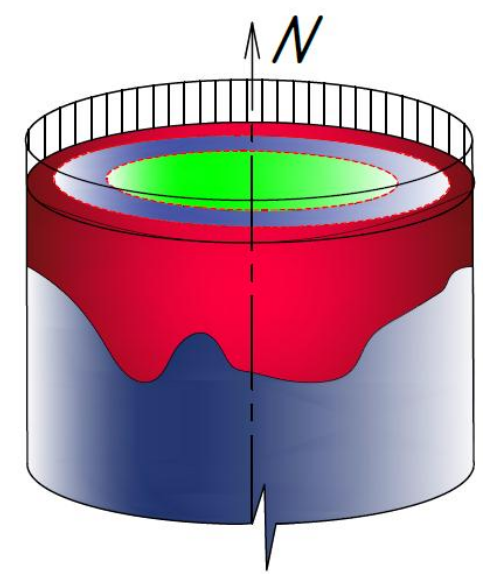

Fig. 3. The principal loading scheme

Therefore, the limit state for steel bar could be identified as for centrally-tensed steel element (eqs. 3-5).

The limit stress value for corresponding level of corrosion will be equal to the yield stress:

$$
\sigma_{\max }=\sigma_{0,2}^{i} \text {. }
$$

Accordingly, the particular limit force will be:

$$
N_{\max }^{i}=\sigma_{\max } \cdot S_{\text {fact }}^{i},
$$

where the steel bar actual area taking into account the corrosion damages:

$$
S_{\text {fact }}^{i}=\frac{\pi \cdot d_{i}^{2}}{4}=\pi \cdot r_{i}^{2}=\pi\left(r_{i n i t}-x_{i}\right)^{2},
$$

where $x_{i}$ - the thickness of corroded layer;

$r_{i}, d_{i}=2 r_{i}-$ the actual steel bar radius and diameter on particular corrosion stage;

$r_{\text {init }}=\frac{d_{\text {init }}}{2}=10 \mathrm{~mm}-$ the initial radius of the rebar before the beginning of corrosion process;

$S_{\text {fact }}^{i}$ - the actual area of steel bar cross-section, taking into consideration the corroded layer thickness;

$\sigma_{0,2}^{i}$ - the yield stress of the rebar material for the particular layer.

The actual values are calculated for different levels of corrosion $x_{i}$ (Table 1) and for corresponding functional equations $f(x)=N_{\max }(x), f(x)=N_{\max }\left(\frac{S_{\text {fact }}^{i}}{S_{\text {innit }}}\right), f(x)=\frac{N_{\max }^{i}}{N_{\text {innit }}}\left(\frac{S_{\text {fact }}^{i}}{S_{\text {innit }}}\right)$ the generalized 6-order polynoms ( see eqs.7) are found with determination coefficient $R^{2}=0,998 \approx 1$.

The generalized form of approximation polynom:

$$
f(x)=a_{1} \cdot x^{6}+a_{2} \cdot x^{5}+a_{3} \cdot x^{4}+a_{4} \cdot x^{3}+a_{5} \cdot x^{2}+a_{6} \cdot x^{1}+a_{7} \cdot x^{0} .
$$

The final equations for limit force decrease evaluation:

$$
\begin{gathered}
N_{\max }(x)=-0,0065 x^{6}+0,2481 x^{5}-3,7301 x^{4}+27,618 x^{3}-99,695 x^{2}+122,6 x^{1}+118,04 x^{0}, \\
N_{\max }\left(\frac{S_{\text {fact }}^{i}}{S_{\text {innit }}}\right)=17674 x^{6}-39704 x^{5}+31706 x^{4}-10662 x^{3}+1593,9 x^{2}+67,867 x^{1}+0,4002 x^{0}, \\
\frac{N_{\max }^{i}}{N_{\text {innit }}}\left(\frac{S_{\text {fact }}^{i}}{S_{\text {innit }}}\right)=86,595 x^{6}-194,53 x^{5}+155,35 x^{4}-52,24 x^{3}+7,3193 x^{2}+0,3325 x^{1}+0,002 x^{0} .
\end{gathered}
$$


BUILDING STRUCTURES

Table 1 - The values of steel bar parameters for corresponding corrosion stage

\begin{tabular}{|c|c|c|c|c|c|}
\hline Stage & $x_{i}, \mathrm{~mm}$ & $\begin{array}{c}\text { Actual } \\
\text { diameter } d_{i}\end{array}$ & $S_{\text {fact }}^{i}, \mathrm{~mm}^{2}$ & $N_{\max }^{i}, \mathrm{kN}$ & $\begin{array}{c}\text { Percentage of } \\
N_{\max }^{i} \text { decrease, } \%\end{array}$ \\
\hline \multirow{6}{*}{$\begin{array}{c}\text { I stage } \\
x_{i} \in[0 ; 2,7], \\
{[\sigma]=650 \mathrm{MPa}}\end{array}$} & 0 & 20 & 314.159 & 204.204 & 0.00 \\
\hline & 0.5 & 19 & 283.529 & 184.294 & 9.75 \\
\hline & 1 & 18 & 254.469 & 165.405 & 19.00 \\
\hline & 1.5 & 17 & 226.980 & 147.537 & 27.75 \\
\hline & 2 & 16 & 201.062 & 130.690 & 36.00 \\
\hline & 2.5 & 15 & 176.715 & 114.864 & 43.75 \\
\hline \multirow{2}{*}{$\begin{array}{c}\text { II stage } \\
x_{i} \in[2,7 ; 3,5], \\
{[\sigma]=545 \mathrm{MPa}}\end{array}$} & 3 & 14 & 153.938 & 83.896 & 58.92 \\
\hline & 3.5 & 13 & 132.732 & 72.339 & 64.58 \\
\hline \multirow{13}{*}{$\begin{array}{c}\text { III stage } \\
x_{i} \in[3,5 ; 10], \\
{[\sigma]=440 \mathrm{MPa}}\end{array}$} & 4 & 12 & 113.097 & 49.763 & 75.63 \\
\hline & 4.5 & 11 & 95.033 & 41.815 & 79.52 \\
\hline & 5 & 10 & 78.540 & 34.558 & 83.08 \\
\hline & 5.5 & 9 & 63.617 & 27.992 & 86.29 \\
\hline & 6 & 8 & 50.265 & 22.117 & 89.17 \\
\hline & 6.5 & 7 & 38.485 & 16.933 & 91.71 \\
\hline & 7 & 6 & 28.274 & 12.441 & 93.91 \\
\hline & 7.5 & 5 & 19.635 & 8.639 & 95.77 \\
\hline & 8 & 4 & 12.566 & 5.529 & 97.29 \\
\hline & 8.5 & 3 & 7.069 & 3.110 & 98.48 \\
\hline & 9 & 2 & 3.142 & 1.382 & 99.32 \\
\hline & 9.5 & 1 & 0.785 & 0.346 & 99.83 \\
\hline & $\rightarrow 10$ & $\rightarrow 0$ & $\rightarrow 0$ & $\rightarrow 0$ & $\rightarrow 100$ \\
\hline
\end{tabular}

The results of analytical evaluation of $N_{\max }^{i}$ decrease were presented graphically (Fig. 4-5) and can be used for further calculations in order to determine the influence of particular corrosion development stage at reinforced concrete element reliability. 


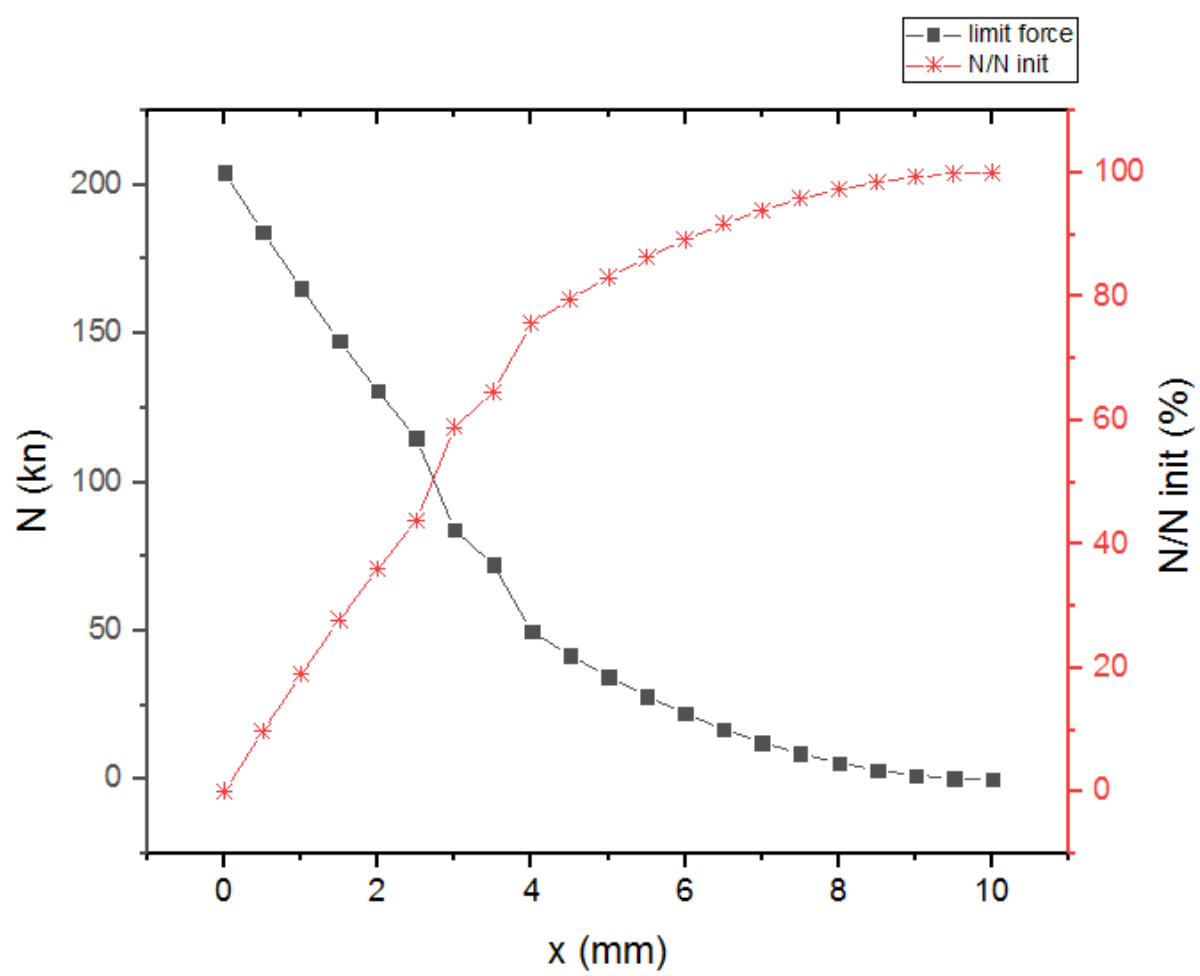

Fig. 4. The graphical presentation of the results for $f(x)=N_{\max }(x)$

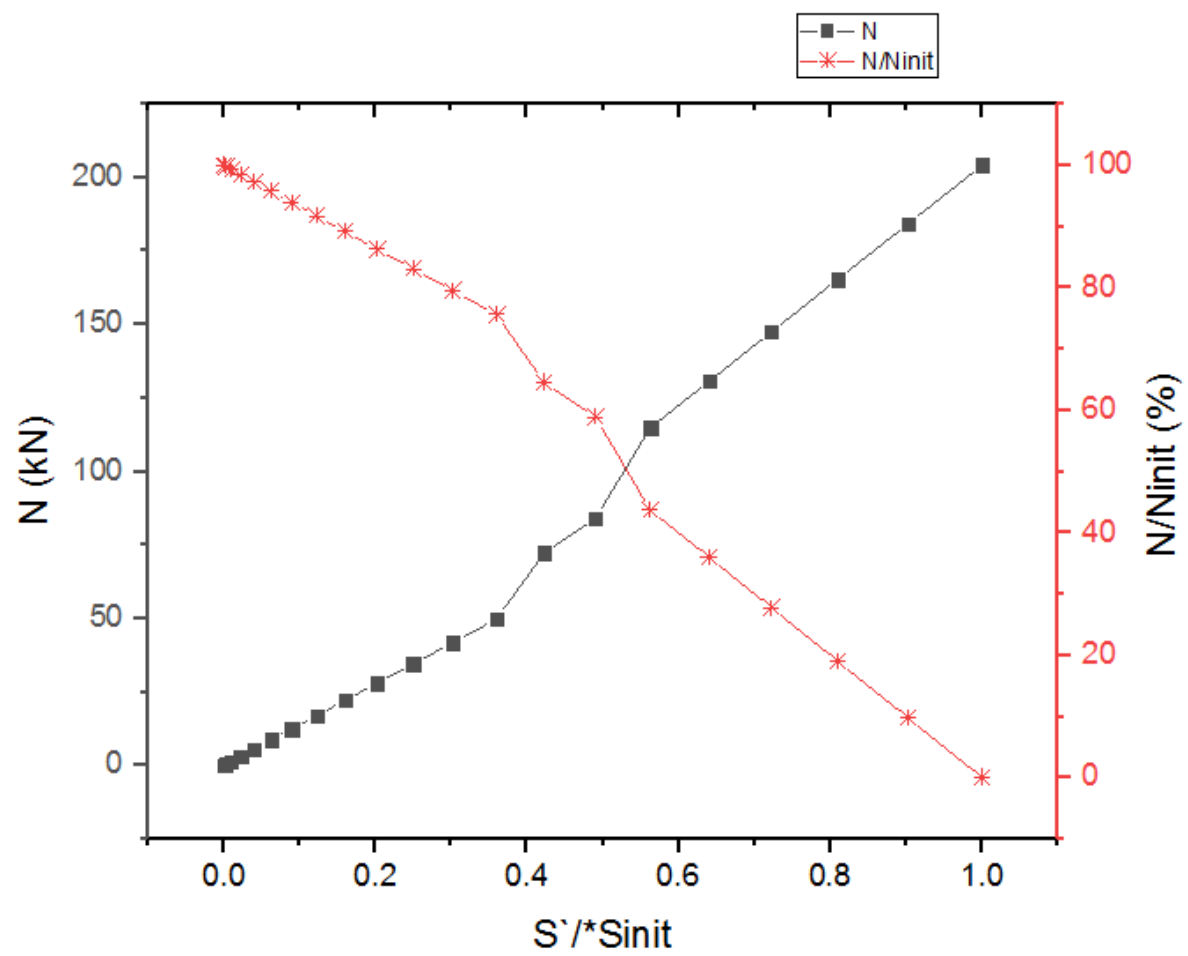

Fig. 5. The graphical presentation of the results for $f(x)=N_{\max }\left(\frac{S_{\text {fact }}^{i}}{S_{\text {innit }}}\right)$

Results of the research. The theoretical modeling of destruction process along the rebar cross section was conducted and obtained results were analyzed.

In this work the major emphasize was made on diameter decrease and corresponding reduction sample reliability. As could be seen from graphical representation of obtained results (Fig.4, 5) the decrease in strength parameters is the sharpest on the first stages of corrosion process 
when destruction process is developed within the thermally-strengthened layer with higher mechanical characteristics. Thus, it is incredibly important to take into account the non-uniform anisotropic structure of the steel rebar along its cross-section. However, it is important to note, that in real situation the corrosion process could be much more complicated than the uniform one, presented in the study. In each particular situation for more complex evaluation the proposed methodology has to be modified through empirical coefficients. In addition, also the time scale factor has to be taken into consideration, as well as layers`chemical properties and microstructure features, because of their different response to the aggressive environmental impact.

Conclusions and perspectives for further research. The method for analytical evaluation of corrosion processes in thermally strengthened rebar was presented in the article. The thorough analysis of obtained results shows that they could be used for further theoretical investigations of this issue and experimental research on particular armature samples. In addition, the thorough literature review of this issue was conducted and main areas, which need to be further investigated, are identified.

It could be concluded, that although the proposed modeling technique is rather perspective for implementation in existing calculation algorithms it represents only the marginal situation of the corrosion process and does not take into account different external factors of particular situation. In order to effectively evaluate the impact of corrosion on reinforced concrete element reliability more detailed theoretical research and experimental approbation is required. Also applicable are real-time observations of existing buildings and structures, subjected to aggressive environment impacts.

\section{References}

[1] A.P. Borysyuk, "Napruzheno-deformovanyi stan zalizobetonnyh balok pidsylennyh pid navantazhanniam stalefibrobetonom I komposytamy pry dii malocyklovyh navantazheny", Zbirnyk naukovych prac "Resurso-ekonomni materialy, konstrukcii, budivli ta technologii», Issue 33, pp. 303-313. 2016.

[2] E.V. Klymenko, M.V. Melnyk, "Do pytannya pro robotu poshkodgennyh zalizobetonnyh konstrukcyi", Visnyk Odeskoi dergavnoi akademii budivnytstva i architektuty, vol. 39, chast 1, pp. 337-342, 2010.

[3] M.P. Koval, Y.V. Molkov, "Zastosuvannya optyko-cyfrovyh metodiv dlya vyznachennya shyryny rozkrytya trishyn u zalizobetonnych konstrukcyyah", «Stalezalizobetonni konstrukcii: doslidgennia, proektuvannia, budivnytstvo,ekspluatacia», Zbirnyk naukovych prac, Issue 12, pp. 141-155, 2018.

[4] V.P. Sharanya, Babu C. Ramesh, K. Saravanan, R.M. Roseline Upagara Pushpam, "Corrosion performance of different reinforcement bars used in concrete structures", International Research Journal of Engineering and Technology (IRJET), vol. 03, Issue 05, pp. 756-759, 2016.

[5] T. Bobalo, Y. Blikharskyy, N. Kopiika, M. Volynets, "Serviceability of RC Beams Reinforced with High Strength Rebar's and Steel Plate", Lecture Notes in Civil Engineering, vol. 47, pp. 25-33, 2019.

[6] Y. Blikharskyy, N. Kopiika, "Research of monitoring and modeling methods of corrosion processes in reinforced concrete elements", Visnyk Odeskoi dergavnoi akademii budivnytstva i architektuty, vol. 77, pp. 29-37, 2019. https://doi.org/10.31650/2415-377X2019-77-29-37

[7] H. Torbati-Sarrraf, A. Poursaee, "Corrosion Improvement of Carbon Steel in Concrete Environment through Modification of Steel Microstructure", Journal of Materials in Civil Engineering, vol. 31, Issue 5, 04019042, 2019.

[8] M. Ueli Angst, "Challenges and opportunities in corrosion of steel in concrete", Materials and Structures, vol. 51, Issue 4, pp. 1-20, 2018.

[9] Q. Yang, Y. Li Zh. Zhou., D. Mao, "Effect of Hot Deformation Process Parameters on Microstructure and Corrosion Behavior of 35CrMoV Steel", Materials, vol. 12, Issue 9, $1455,2019$. 
[10] L. Toth, F. Haraszti, T. Kovacs, "Heat treatment effect for stainless steel corrosion resistance", European journal of materials science and engineering, vol. 3, Issue 2, pp. 38-42, 2018.

[11] A. Fahim, A.E. Dean, M.D.A. Thomas, E.G. Moffatt, "Corrosion resistance of chromium-steel and stainless steel reinforcement in concrete", Materials and Corrosion, vol. 70, Issue 2, pp. 328-344, 2019.

[12] J. Shi, J. Ming, W. Sun, Y. Zhang, "Corrosion performance of reinforcing steel in concrete under simultaneous flexural load and chlorides attack", Construction and Building Materials, Issue 149, pp. 315-326, 2017.

[13] W.S. Labiaparia, M.A.N. Ardila, C. Binder, H.L. Costa, J.D.B. de Mello, "Mechanical effects on the corrosion resistance of ferritic stainless steels", Wear, pp. 1475-1481, 2018.

[14] Y.Z. Blikharskyy, "Mechanical Properties of Thermally Hardened A500s Reinforcement", Mater Sci, vol. 55, pp. 175-180, 2019.

\title{
ВПЛИВ РІВНОМІРНОЇ КОРОЗІЇ СТАЛЕВОЇ АРМАТУРИ НА МІЦНІСТЬ ЗАЛІЗОБЕТОННИХ КОНСТРУКЦІЙ
}

\author{
${ }^{1}$ Бліхарський Я.3., к.т.н., доцент, \\ Yaroslav.Z.Blikharskyy@lpnu.ua, ORCID: 0000-0002-3374-9195 \\ ${ }^{1}$ Копійка Н.С., студентка, \\ kopijka.nadija.1999@gmail.com, ORCID: 0000-0003-2270-4028 \\ ${ }^{1}$ Національний університет «Львівська політехніка» \\ вул. С. Бандери 12, м. Львів, 79013, Україна
}

\begin{abstract}
Анотація. Широке використання залізобетонних конструкцій в різних областях, характерне для нагальної будівельної практики, можна пояснити через ряд їх переваг. Дані переваги, що включають різноманітність можливих конструктивних i архітектурних форм, високу довговічність і міцність, відносно невисоку ціну завдяки можливості використання місцевих матеріалів і скорочення витрат на виготовлення, монтаж і експлуатацію в основному спричинені композитним характером складу даного матеріалу і синергічною взаємодією його складових компонентів. Однак, слід враховувати кількість ускладнюючих аспектів, включаючи вплив агресивного середовища та корозійні процеси як у бетоні, так і в арматурі. Вплив корозійних процесів на існуючі конструкції на сьогодні є визначальним фактором зниження їх надійності і експлуатаційної придатності. В даній статі за мету поставлено визначення і чітка ідентифікація основних факторів корозійного процесу. Як конкретний приклад розглянуто особливості зниження міцнісних параметрів термічно-зміцненої арматури при поширенні в ній кородованого шару, як широко поширеної ситуації в практиці проектування. В роботі проведено аналітичне моделювання рівномірного типу корозії в радіальному напрямку 3 огляду на пошарову анізотропію арматурної сталі. Отримані результати можуть бути в подальшому застосовані для теоретичних досліджень i чисельного моделювання, a також для експериментальної апробації. Перспективною є можливість їх використання для комплексної оцінки впливу корозійних процесів на несучу здатність і надійність залізобетонного елемента загалом. Необхідно, однак, зазначити, що розглянута модель корозії є досить спрощеною i характеризує лише граничний випадок поширення зруйнованого шару в масиві матеріалу. Для більш точної ідентифікації конкретної ситуації необхідне емпіричне її коригування. Додатково зроблено детальний огляд літератури і аналіз наявних досліджень 3 даного питання. Зроблено висновок, що дослідженню проблемам корозії в залізобетонних елементах загалом і в арматурних сталях анізотропної структури необхідно приділити більшу кількість теоретичних досліджень. Також важливою для оцінки отриманих результатів є формування докладної і достовірної бази експериментальних даних лабораторних випробувань окремих зразків i наочних технічних оглядів реально існуючих конструкцій і споруд.
\end{abstract}

Ключові слова: корозія в залізобетонних елементах, рівномірна корозія сталі, термічно зміцнена арматура, аналітичне моделювання.

Bulletin of Odessa State Academy of Civil Engineering and Architecture, 2020, no. 79, page 34-42 


\title{
ВЛИЯНИЕ РАВНОМЕРНОЙ КОРРОЗИИ СТАЛЬНОЙ АРМАТУРЫ НА ПРОЧНОСТЬ ЖЕЛЕЗОБЕТОННЫХ КОНСТРУКЦИЙ
}

\author{
${ }^{1}$ Блихарский Я.3., к.т.Н., доцент, \\ Yaroslav.Z.Blikharskyy@lpnu.ua, ORCID: 0000-0002-3374-9195 \\ ${ }^{1}$ Копийка Н.С., студентка, \\ kopijka.nadija.1999@gmail.com. ORCID: 0000-0003-2270-4028 \\ ${ }^{1}$ Национальный университет «Львовская политехника» \\ ул. С. Бандеры 12, г. Львов, 79013, Украина
}

\begin{abstract}
Аннотация. Широкое использование железобетонных конструкций в различных областях, характерное для имеющейся строительной практики, можно объяснить через ряд их преимуществ. Данные преимущества, включающие разнообразие возможных конструктивных и архитектурных форм, высокую долговечность и прочность, относительно невысокую цену благодаря возможности использования местных материалов и сокращение затрат на изготовление, монтаж и эксплуатацию в основном вызваны композитным характером состава данного материала и синергическим взаимодействием его отдельных компонентов. Однако, следует учитывать количество усложняющих аспектов, включая воздействие агрессивной среды и коррозионные процессы как в бетоне, так и в арматуре. Влияние коррозионных процессов на существующие конструкции на сегодня является определяющим фактором снижения их надежности и эксплуатационной пригодности. В данной статье целью поставлено определение и четкая идентификация основных факторов коррозионного процесса. В качестве конкретного примера рассмотрены особенности снижение прочностных параметров термически-укрепленой арматуры при распространении в ней кородованого слоя, как широко распространенной ситуации в практике проектирования. В работе проведено аналитическое моделирование равномерного типа коррозии в радиальном направлении с учетом пошаровой анизотропии арматурной стали. Полученные результаты могут быть в дальнейшем использованы для теоретических исследований и численного моделирования, а также для экспериментальной апробации. Перспективной является возможность их использования для комплексной оценки воздействия коррозионных процессов на несущую способность и надежность железобетонного элемента в целом. Необходимо, однако, отметить, что рассматриваемая модель коррозии является достаточно упрощенной и характеризует лишь предельный случай распространения разрушенного слоя в массиве материала. Для более точной идентификации конкретной ситуации необходимо эмпирическое ее корректирование. Дополнительно сделано подробный обзор литературы и анализ имеющихся исследований по данному вопросу. Сделан вывод, что исследованию проблемам коррозии в железобетонных элементах в общем и арматурных сталях анизотропной структуры в частности необходимо уделить большее количество теоретических исследований. Также важной для оценки полученных результатов является формирование подробной и достоверной базы экспериментальных данных лабораторных испытаний отдельных образцов и наглядных технических осмотров реально существующих конструкций и сооружений.
\end{abstract}

Ключевые слова: коррозия в железобетонных элементах, равномерная коррозия стали, термически усиленная арматура, аналитическое моделирование.

Стаття надійшла до редакції 27.03.2020 